\title{
U źródła legendy poetyckiej biskupa krakowskiego Kajetana Sołtyka
}

\section{Krystyna Maksimowicz}

ORCID: OOOO-OOOI-7545-9228

(Uniwersytet Gdański / Państwowa Wyższa Szkoła Zawodowa w Elblągu)

Dedykowany pamięci Profesora Janusza Maciejewskiego jubileuszowy numer „Napisu” dostarczył okazji ku temu, by przywołać dzieło życia Pana Profesora, które unieśmiertelniło Jego imię uczonego. Mam na myśli nie do przecenienia czterotomową Literaturę konfederacji barskiej ${ }^{\mathrm{I}}$, przygotowaną pod redakcją Jego oraz Zespołu, w skład którego weszli Agnieszka Bąbel, Agata Grabowska-Kuniczuk i Jacek Wójcicki. To monumentalne dzieło - często wykorzystywane w badaniach naukowych - było rezultatem pracowitych kwerend archiwalno-bibliotecznych, prowadzonych w kraju i poza nim. Na mapie wyjazdów badawczych Zespołu znalazł się także Gdańsk, a ściślej mówiąc, zbiory Profesora Edmunda Rabowicza, niestrudzonego poszukiwacza literatury okolicznościowej, więc miałam okazję widzieć, jak Profesor Maciejewski pasjonował się literaturą barską, z jaką determinacją dążył do zebrania wszystkich tekstów barskich, jak skrupulatnie odnotowywał i porównywał przekazy rękopiśmienne. Temu wielkiemu zaangażowaniu Profesora zawdzięczamy edycję literatury barskiej.

Ponieważ postać biskupa krakowskiego Kajetana Sołtyka zajmuje w literaturze tego okresu ważne miejsce, zachęciło mnie to do podjęcia próby nakreślenia konterfektu biskupa z tego czasu, ukazania kształtującej się wówczas jego pozytywnej legendy poetyckiej. Ogólnie rzecz ujmując, można by ten wizerunek oddać słowami

1 Zob. Literatura konfederacji barskiej, t. 1: Dramaty, t. 2: Dialogi, t. 3: Wiersze, t. 4: Silva rerum, red. J. Maciejewski, A. Bąbel, A. Grabowska-Kuniczuk, J. Wójcicki, Warszawa 2005-2009. W opracowywaniu utworów brały udział następujące osoby: Agnieszka Bąbel, Paweł Dudziak, Małgorzata Elżanowska, Agata Grabowska-Kuniczuk, Wojciech Kaliszewski, Agnieszka D. Kawka, Janusz Maciejewski, Edmund Rabowicz, Magdalena Rudkowska, Katarzyna Sałkiewicz, Bożena Samojluk, Roman Sobol, Zbigniew Sudolski, Bartłomiej Szleszyński, Katarzyna Wąsala, Barbara Wolska, Jacek Wójcicki. 
Friedricha Schulza: „Pięcioletnia niewola w Rosji, którą nań wybuchy gorliwości ściągnęły, jego i rodzinę otoczyła aureolą męczeństwa" ${ }^{2}$ Ta ocena podróżującego po Polsce w latach I79I-I793 „Inflantczyka”, a więc spojrzenie z perspektywy ponad dwudziestu lat, świadczyło o tym, że ukształtowany w literaturze barskiej martyrologiczny konterfekt biskupa walczącego o dominację Kościoła katolickiego w Polsce ciągle był żywy. Zmarły na przedpolu Sejmu Wielkiego Kajetan Sołtyk - dawny więzień Kaługi - nie stracił nic na swym wizerunku gorliwego obrońcy wiary Chrystusowej oraz ofiary Stanisława Augusta i ambasadora Nikołaja Repnina. W czteroleciu sejmowym, gdy dokonywano dzieła uchwalenia Konstytucji 3 maja, a następnie podejmowano rozpaczliwe próby ocalenia kraju, Kajetan Sołtyk pozostał symbolem poświęcenia dla ojczyzny i heroicznej walki o wielką sprawę.

Niemal wszystkie wiersze barskie odnoszące się do bohatera tego studium mają charakter pochwalny; głoszą apoteozę więźnia gotowego ponieść największą ofiarę w imię obrony wartości religijno-patriotycznych. W sytuacji ekstremalnej, czyli zniewolenia i związanej z tym niepewności życia, zepchnięty z piedestału hierarcha Kościoła budził szacunek swą wiernością ideałom, wyzwalał współczucie, mobilizował do oporu w sprawie różnowierców i dawał nadzieję na zwycięstwo. Jego przykład miał krzepić ducha konfederatów i być drogowskazem w ich działaniu.

W poniższym artykule oglądamy portret Sołtyka głównie przez pryzmat wierszy anonimowych, bo właśnie ten rodzaj twórczości bezimiennej stanowił większość w całej literaturze barskiej. Wiersze autorskie - w tym powstałe w kręgu rodzinnym biskupa - przegrywają pod względem liczebności z tekstami bezimiennymi. $Z$ rozważań wyłączono dramaty barskie oraz rymowany pamiętnik Józefa Jędrzeja Załuskiego, czyli dzieła dłuższe i budzące większe zainteresowanie badaczy aniżeli wykorzystane $\mathrm{w}$ tej rozprawie utwory. Za takim wyborem przemawia też fakt pisania ich „na gorąco”, z autopsji, co oznacza, że bardziej niż te tworzone z pewnej perspektywy uwiarygodniały autentyczność emocji autorów i były pozbawione retuszu w zakresie przekazywanych treści.

Odnoszące się do Kajetana Sołtyka utwory z czasu niewoli kałuskiej stały się zaczątkiem budowania jego pozytywnej legendy poetyckiej. Mimo iż biskup wykazywał przed sejmem duże zaangażowanie w sprawę dysydentów i głośno artykułował obawy związane $\mathrm{z}$ obradami, to zwlekano z jego aresztowaniem. Licząc się z możliwością deportacji, miał powiedzieć: „Jestem zdecydowany; jeśli przywiążą mnie do ogona końskiego i powloką na Syberię, rad z tego będę, mając wewnętrzne przeświadczenie, że spełniłem jedynie moją powinność i uczyniłem to, czego obo-

2 F. Schulz, Podróże Inflantczyka z Rygi do Warszawy i po Polsce w latach 1791-1793, tłum. J.I. Kraszewski, w: Polska stanistawowska w oczach cudzoziemców, t. 2, oprac. i wstępem poprzedził W. Zawadzki, Warszawa 1963, s. 664. 
wiązek i sumienie domagały się ode mnie”, co powtarzamy za Jakubem Harrisem, dyplomatą angielskim i obserwatorem wydarzeń w Polsce w i767 roku ${ }^{3}$. Odnosząc się dalej do zachowania Sołtyka w okresie poprzedzającym konfederację barską, Harris dokonał następującej oceny jego działalności: „nie zadowolił się jedynie przemawianiem przeciw postępowaniu Rosji, ale - mając do tego prawo jako senator - rozesłał do wszystkich sejmików okólne listy, przedstawiając im niebezpieczne ich położenie i ucisk, którego należało oczekiwać, oraz napominając ich, by mężnie stali przy swej wierze i prawach"4. Ten zwięźle ujęty pogląd Anglika na temat zaangażowania Kajetana Sołtyka w wypadki poprzedzające jego deportację do Rosji był zgodny z powszechnymi odczuciami opinii publicznej.

Anonimowy Wiersz na tę mowę, po której pierwszej zaraz nocy wzięty w areszt pomieniony biskup [Sołtyk - K. M.] pozwala przyjąć, że wygłoszona przez Sołtyka $\mathrm{w}$ dniu aresztowania oracja postawiła przysłowiową kropkę nad „i” w sprawie uprowadzenia go do niewoli, co stało się w nocy z I3 na I4 października I767 roku. Emocjonalnego, antyrosyjskiego wystąpienia pod tytułem Mowa J.O. Księcia Jmci Sottyka biskupa krakowskiego die I3 8-bris I767 do Senatu przygotowana, ale dla wzięcia tegoż księcia w areszt przez Moskwę w Senacie nie miana, tylko na sesji prowincjonalnej matopolskiej czytana ${ }^{5}$, wysłuchali posłowie małopolscy w pałacu biskupim. W oracji tej Sołtyk postawił się poniekąd w roli rzecznika opozycjonistów. Jego narracja poszła tak daleko, że nie wahał się wołać rozpaczliwie: „O, epoko nieszczęśliwa największej i ostatniej klęski naszej! O, czasie w okrągu wieczności miejsca mieć niegodny! Czemu-żem cię śmiercią moją nie uprzedził?”, a występując przeciwko traktatowi z Rosją i wojsku rosyjskiemu w Polsce, grzmiał: „Kto z sąsiadów granice nasze najeżdża? Kto nas gwałtownie uciska? Jeżeli zaś na wewnętrzne nasze zamieszanie obcych posiłków zaciągamy, o, hańbo narodu!”. By przekonać słuchaczy do głoszonych racji, oddziaływał na ich ambicję i dumę, przypominał wspaniałych przodków, jednocześnie nakazując obecnym trwać w obronie najświętszych wartości:

\section{Przodkowie bronili wiary - dacie im na Sądzie Boskim rachunek, i potomkom, jeśli wiarę i wolność zgubicie [...]. Patrzy na was Bóg}

3 Zob.J.Harris, Dziennik pobytu w Polsce 1767, tłum. Z. Lewinówna, w: Polska stanistawowska w oczach cudzoziemców, t. 1, oprac. i wstępem poprzedził W. Zawadzki, Warszawa 1963, s. 292.

4 Ibidem, s. 292-293.

5 Zob. Mowa J.O. Księcia Jmci Sottyka biskupa krakowskiego die 13 8-bris 1767 do Senatu przygotowana, ale dla wzięcia tegoż Księcia w areszt przez Moskwę w Senacie nie miana, tylko na sesji prowincjonalnej matopolskiej czytana, rkps BUW 274, t. 1, s. 11-33 (w: Rękopis czyli zbiór rozmaitych pisem jako to politycznych krajowych, historycznych $i$ ciekawych etc...). Cytowane fragmenty pochodzą z tego manuskryptu. Zob. M. Czeppe, Sottyk Kajetan Ignacy, hasło w: Polski stownik biograficzny (dalej: PSB), t. 40, Warszawa 2001, s. 396. 
jako wy sobie w jego sprawie postąpicie i równą czynnościom waszym gotuje wam nagrodę. Uwieńczy was chwałą lub się was wstydzić będzie na wieki. Modli się za was Kościół i czeka od was skutku obietnic przez was na chrzcie oświadczonych. Płacząca ojczyzna [...] doprasza się od was tej ostatniej toni dowodów powinnej miłości. Oczekuje świat cały, co o was ma powiedzieć, czyliście niegodne przodków naszych plemię, czyli synowie wolności [...]. Czy imiona z chwałą, czy z największą plamą i upodlenie następującym ma podać wiekom?

Upamiętniający to głośne wystąpienie Sołtyka autor Wiersza na tę mowę, po której pierwszej zaraz nocy wzięty w areszt pomieniony biskup podał szczegóły związane $\mathrm{z}$ aresztowaniem:

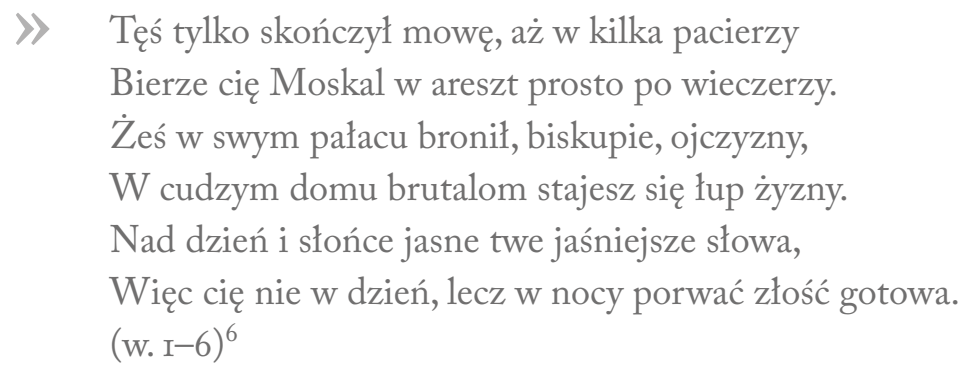

Apostrofa pełniła w utworze ważną funkcję: przydano mu charakter informacyjny. Prawdopodobnie wiedza o porwaniu Sołtyka nie była wówczas jeszcze powszechna, a kompetentny w tej sprawie składacz rymów chciał jak najszybciej upublicznić bulwersującą wiadomość. Możliwe, że był on naocznym świadkiem wygłoszonej przez biskupa mowy, a w każdym razie znał realia odnoszące się do porwania: jako miejsce aresztowania wskazał „cudzy dom”, czyli pałac marszałka nadwornego koronnego Jerzego Augusta Mniszcha, u którego Sołtyk gościł na kolacji. Fakt aresztowania biskupa $\mathrm{w}$ rezydencji Mniszcha znajduje potwierdzenie w relacji Stanisława Augusta, dopełnionej szczegółami, że dokonał tego pułkownik Igelström, przybyły do siedziby marszałka $\mathrm{z}$,kilkoma setkami rosyjskich sołdatów”, którzy sforsowali drzwi wejściowe do pałacu, a następnie - odnalazłszy biskupa w sypialni - poinformowali go o areszcie. Potem „doprowadzono Sołtyka do powozu, który zawiózł go do ogrodu domu Repnina”.

6 Wiersz na tę mowee, po której pierwszej zaraz nocy wzięty w areszt pomieniony biskup, oprac. J. Maciejewski, w: Literatura konfederacji barskiej, t. 3, s. 15.

7 Pamiętniki króla Stanistawa Augusta. Antologia, t. 5, wybór tekstu D. Triaire, tłum. W. Brzozowski, wstęp A. Grześkowiak-Krwawicz, red. M. Dębowski, Warszawa 2013, s. 317-318 (t. 5). Zob. M. Czeppe, Sottyk Kajetan Ignacy, s. 396. 
Autor wiersza nie miał wątpliwości, że chociaż haniebny czyn porwania odbył się pod osłoną ciemności, to głośna mowa biskupa będzie ,jaśniała nad słońce”, a tym samym nie można będzie ukryć bezprawia dokonanego pamiętnej nocy z I3 na I4 października I767 roku. Upersonifikowana „złość, zadająca gwałt biskupowi, nie wymaże imienia Sołtyka z pamięci ludzkiej i przyniesie inny niż zamierzony skutek, gdyż - jak przewidywał rymopis - rozsławi na wieki wystąpienie biskupa: „coś napisał i coś mówił właśnie, / Z sławą imienia twego na wieki nie zgaśnie” (w. 7-8).

Niezorientowany co do miejsca aresztowania Sołtyka anonimowy twórca Wieczernika warszawskiego wskazał na dom powiązanego z Rosją podskarbiego Teodora Wessla:

\section{Chrystusowy podskarbi, rzecz jest niesłychana, Judasz, zdrajca, gdy myślał na śmierć wydać Pana, Umówił się z zdrajcami, jak robią nieszczerzy, Żeby go po ostatniej pojmali wieczerzy; Gdy areszt krakowskiego biskupa, zuchwale Wziętego podczas nocy, zważam, przez Moskale, Przyznać muszę, że na kształt chytrego Judasza \\ $\mathrm{Na}$ wieczerzę go w cudzy dom kształtnie zaprasza. (w. I-8)}

Niezależnie od tego, jaką rolę - większą czy mniejszą - odegrał Judasz-Wessel w sprawie aresztowania Sołtyka, poeci obwiniali go o niecny postępek wydania biskupa na łup ciemiężyciela, dostrzegając podobieństwo między sprzedanym przez Judasza Jezusem i zdradzonym przez rodaków Sołtykiem.

Reakcje na dokonane nocą bezprawie płynęły z różnych stron i środowisk. Były to spontaniczne wiadomości, przekazywane przez naocznych świadków zdarzeń, kompetentnych lub mniej wtajemniczonych autorów, jak też przez rzekomego „idiotę”, czyli prostego człowieka, który gwałt zadany biskupom nocą oraz cały kontekst $\mathrm{z}$ tym związany uznał za bezprzykładny. Bohater wiersza Lament idyjoty idqcego z Warszawy nad wzięciem biskupów za wiarę święta i wolność obstawających wołał zbulwersowany:

\section{》 [...] Więcej ja widziałem w Warszawie, Gdzie pojmali biskupów okrutnie i żwawie Moskale, że przy wierze jednostajnie stali,}

8 Wieczernik warszawski die 13 octobris 1767, oprac. E. Rabowicz, w: Literatura konfederacji barskiej,t. 3, s. 13. 
Za to, że dysydentom brać góry nie dali.

Biorą w nocy jednego przez warty i straże;

Choćby z łóżka, bierz gwałtem, bo tak starszy każe.

Drugiemu jadącemu zastępują drogę,

Ciągną z karety, mówiąc: „Pódź w niemałą trwogę!”

(w. $7-\mathrm{I} 4)^{9}$

Piszący z pozycji zwykłego obserwatora autor przeżywał bezprawie dokonane na biskupach - niczym Katon upadek Rzymu. Było to śmiałe zestawienie wielkiej postaci historycznej z Sołtykiem; być może w tym obrazowaniu krył się tak daleko idący lęk autora o porwanych do niewoli obrońców wiary, że nie wykluczał dla nich losu Katona. Heroiczny czyn samobójczy rzymskiego polityka, u podstaw którego leżały silne emocje związane z upadkiem republiki (zwycięstwo Cezara pod Tapsus), mogły wzniecić złe przeczucia w duszy wierszopisa, zwłaszcza że od chwili uprowadzenia senatorów przekazywane na ten temat informacje bywały sprzeczne. Zestawiając w utworze „tyranię” Cezara z haniebnym czynem Moskali w Warszawie, autor próbował uczynić rzymskiego wodza bardziej ludzkim („Chociaż cesarz kapłanów zachował bezpiecznie”, w. 4) niż Moskale, którzy porywali obrońców wartości chrześcijańskich.

By rozwiać wszelkie wątpliwości na temat okoliczności aresztowania i losu Sołtyka, był potrzebny głos autorytetu. W tym przypadku najbardziej przekonywałaby wypowiedź samego więźnia. Taką konstrukcję nadano wierszowi pt. Lament ojczyzny nad wziętymi synami, w którym w usta Sołtyka włożono słowa:

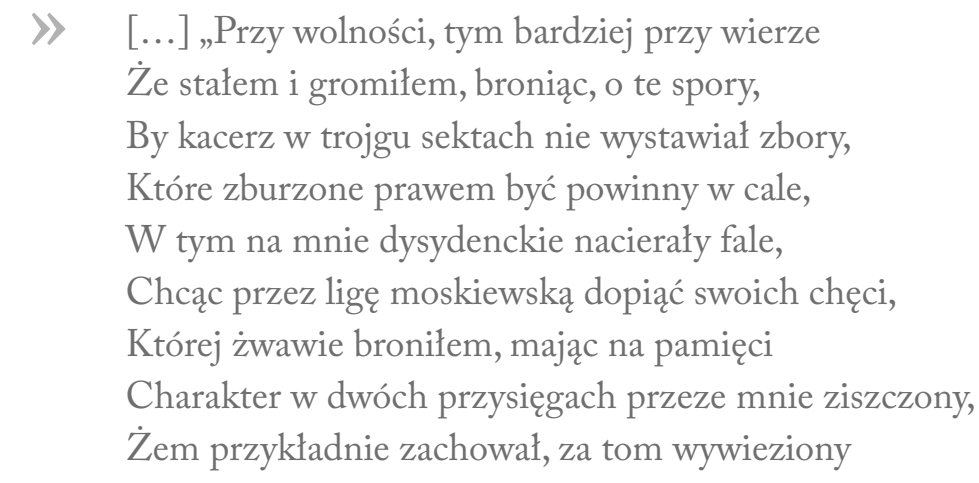

9 Lament idyjoty idacego z Warszawy nad wzięciem biskupów za wiarę święta i wolność obstawajacych, wydany roku 1768, oprac. A. Grabowska-Kuniczuk, w: Literatura konfederacji barskiej, t. 3, s. 44. Wprowadzona do wiersza postać Cezara skłania do refleksji nad często negatywnie ocenianym jego wizerunkiem w XVIII stuleciu. Przykładem jest emocjonalny List Katona Utyckiego do Cezara (oprac. J. Wójcicki, w: Literatura konfederacji barskiej, t. 3, s. 264-273), znacznie radykalniejszy w oskarżeniach (między innymi Cezar przykładem „pychy, łakomstwa, zabójstw, cudzołóstwa, zdrady”, w. 74) niż w utworze Lament idyjoty. 
Gwałtownie, spośród miasta, w noc, w późną godzinę.

Przełożyłem ci, Matko, i skargę, i winę”.

(w. 22-32) $)^{\text {IO }}$

W wypowiedzi tej zabrakło co prawda precyzji dotyczącej wskazania konkretnego domu, z którego uprowadzono biskupa, bo (jak można sądzić) nie to było najważniejsze, ale fakt dokonania gwałtu na obrońcy wolności i wiary, do tego w godzinach nocnych, miał poruszyć sumieniami rodaków, wzbudzić empatię, a być może wzmocnić ducha w tych, w których „staropolskiej cnoty [...] niewiele” (w. I2).

Wprowadzenie do utworu postaci Sołtyka miało duże znaczenie, gdyż nie była to relacja z drugiej ręki, ale głos uwięzionego hierarchy Kościoła, autorytetu moralnego, postaci wyjątkowej, na co zresztą wskazuje sytuowanie go w wierszach barskich w kontekście męczenników, świętych, bohaterów (proroków) biblijnych i antycznych.

Tomasz Ślęczka podał, że wśród konfederatów największą popularność spośród osób kanonizowanych zyskał święty Kazimierz, aczkolwiek - jak zaznacza autor - fakt ten nie znalazł odzwierciedlenia w literaturze okresu. Pod względem popularności dystansował go święty Stanisław, najczęściej ukazywany w opozycji do Bolesława Śmiałego ${ }^{\text {II }}$. Przedstawianie biskupa Stanisława jako ofiary porywczego władcy stanowiło czytelne nawiązanie do konfliktu Kajetana Sołtyka ze Stanisławem Augustem.

W anonimowym wierszu Ksiażę biskup krakowski Sottyk (w cyklu Zdanie o biskupach na sejmie teraźniejszym przy wierze $i$ wolności obstajacych ${ }^{7767)}$ ) autor był gotów przyznać Sołtykowi więcej chwały niż „rozsiekanemu na Skałce przez złość króla” (w. 4) świętemu Stanisławowi. Co więcej, tenże twórca poszedł w swych skojarzeniach jeszcze dalej: zestawił niewolę Sołtyka także z losem świętego Wojciecha, łącząc obie postaci na zasadzie misyjnego posłannictwa. Wypełniona przez nich misja apostolska została okupiona wielką ofiarą: biskup krakowski cierpiał w srogiej niewoli, a święty Wojciech zginął jako męczennik z rąk Prusów. W przeświadczeniu autora męczeństwo biskupa Kajetana, chętnie podejmującego niewolę, byleby się ostała w kraju święta wiara katolicka, znalazło wspólną płaszczyznę martyrologiczną na poziomie biografii obu świętych, Stanisława i Wojciecha:

\section{Jeżeli nie przewyższy, to lustr przyda spory. Wojciecha, Stanisława swych przodków honory Jeden z tych od Prusaków męczennik przez rany,}

10 Lament ojczyzny nad wziętymi synami, oprac. J. Maciejewski, w: Literatura konfederacji barskiej, t. 3, s. $11-12$.

11 Zob. T. Ślęczka, Historia Polski w literaturze barskiej. Próba charakterystyki, w: Poezja okolicznościowa w Polsce w latach 1730-1830. W kregu spraw publicznych i narodowych, red. M. Nalepa, G. Trościński, R. Magryś, Rzeszów 2014, s. 210-212. 
Drugi na Skałce przez złość króla rozsiekany.

Ten zaś srogą niewolę chętnie podejmuje,

A niech wiara i wolność w Królestwie panuje.

(w. I-6) $)^{\mathrm{I2}}$

Zestawianie Sołtyka ze świętymi otaczanymi szczególnym kultem miało konkretny cel. Zgodnie z kreacją postaci świętego w literaturze barskiej - na zamordowanym spoczywała poniekąd powinność wspomagania następców, a takiej pomocy niewątpliwie potrzebował więziony duchowny. Anonimowy autor Pieśni do świętego Stanistawa biskupa krakowskiego wołał rozpaczliwie, ale też z nadzieją:

Stanisławie, sławny męczenniku,

Nasz przed Bogiem wierny pośrzedniku,

Wolność z wiarą zaprzedane,

Prawa dawne połamane,

Ludu twego miłośniku!

$[\ldots]$

Stanisławie, czyli cię nie dręczy,

Że następca twój w niewoli jęczy? -

Proś zastępów z nami Pana,

Nieprzyjaciel Kajetana

Niech dłużej nie męczy.

(w. II-I5, $46-50)^{\mathrm{I} 3}$

Twórcy pieśni barskich zwracali się do wielu świętych patronów Polski o opiekę nad więźniami. Autor utworu o incipicie: „Oddaj się, Lechu, w opiekę Maryi” wiązał nadzieje z mocą sprawczą Matki Boga, z pomocą, jaką niesie potrzebującym, a takimi są właśnie teraz cierpiący w niewoli obrońcy wiary Chrystusowej. W związku z tym przeświadczeniem zostaje silnie wyartykułowana prośba autora:

\section{》 Miej w Twojej straży w więzieniu Polaków, Obrońców prawa, wiary jedynaków,}

12 Książe biskup krakowski Sottyk (w cyklu Zdanie o biskupach na sejmie teraźniejszym przy wierze $i$ wolności obstających 1767), oprac. J. Maciejewski, w: Literatura konfederacji barskiej, t. 3, s. 26.

13 Pieśn do świętego Stanistawa biskupa krakowskiego (w cyklu Konfederatów barskich pieśni $i$ modlitwy), oprac. J. Maciejewski, w: Literatura konfederacji barskiej, t. 3, s. 485-488. 
Którzy, na prawa, mówiąc, fundamencie,

Wzięci w niewolą, siedzą w Dyjamencie.

Czyli w Smoleńsku w moskiewskiej krainie;

Przy Twej opiece niech żaden nie zginie,

Bo ta niewola i ścisłe więzienie

Będzie ich sławą i wiary zmocnienie.

(w. $4 \mathrm{I}-48)^{\mathrm{I} 4}$

Autor wierzy, że wstawiennictwo Maryi u Syna sprawi, iż więźniowie ocalą życie, a poniżony w niewoli herb Sołtyka będzie jak dawniej błyszczeć: „Orła Sołtyków nie zszpeci kandoru", czyli zachowa świetność (w. 56).

Przy okazji tego wiersza wypada wtrącić wyjaśnienie dotyczące „Dyjamentu”; jak objaśnił wydawca utworu - mowa o twierdzy w Rydze, w której między innymi więziono konfederatów. Okazuje się, że autor pieśni nie miał wiarygodnych wiadomości o miejscu deportacji senatorów. Wśród różnych plotek na ten temat rzeczywiście pojawiała się Ryga, ale był to tylko nietrafiony domysł, mogący zresztą stanowić wskazówkę do chronologizacji tekstu.

Inny anonimowy twórca sięgnął po kontekst biblijny w Lamentacyi Jeremijasza nad Krakowem I768 Anno, by wyrazić ból, ale też nadzieję, że cierpienie, jakiego doznaje biskup, może przynieść coś pozytywnego: „Da Bóg, że się wiara i wolność ocali" (w. 82).

\section{$\gg \quad[\ldots]$ biskup krakowski \\ Jakie cierpi dla wiary mozoły i troski! \\ Widzieć go, jak drugiego ze lwy Danijela. \\ Gdyby dał Bóg ojczyźnie innych takich wiela, \\ Nie poszłaby w rozsypkę Chrystusowa trzóda. \\ (w. 69-73) $)^{15}$}

Aluzja do biblijnego proroka Daniela miała głęboką wymowę; pozwalała widzieć w Sołtyku pasterza bezgranicznie oddanego Bogu, mogącego liczyć na cud ocalenia z wielkiego niebezpieczeństwa. Podobnie jak Daniel za swoją wierność Bogu, za co z rozkazu króla Dariusza został wtrącony do jaskini lwów i wyszedł z tego cało, tak samo cierpiący w niewoli w imię heroicznej obrony wiary Chrystusowej Sołtyk

14 Pieśń czwarta (w cyklu jw.), oprac. J. Maciejewski, w: Literatura konfederacji barskiej, t. 3, s. 480-482.

15 Lamentacyja Jeremijasza nad Krakowem 1768 anno, oprac. J. Maciejewski, w: Literatura konfederacji barskiej, t. 3, s. 307-309. 
- zdaniem poety - może odnieść zwycięstwo, powrócić $\mathrm{z}$ więzienia niepokonany. Wprowadzony do Lamentacyi motyw Daniela wykazuje podobieństwo z ujęciem w średniowiecznym Wierszowanym liście króla Wtadystawa. Wiersz, powstały po przegranej bitwie pod Warną, gdy wierzono jeszcze w powrót króla łączonego z ideologią przedmurza chrześcijańskiego, miał przeciąć wszelkie spekulacje na temat jego losu. Czytamy w nim:

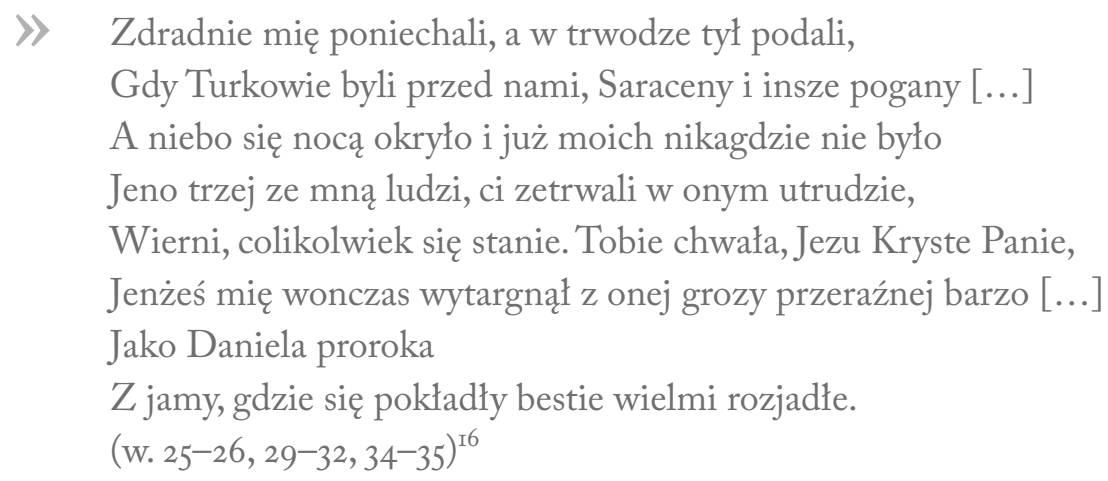

Podobnie stało się z Sołtykiem, którego miejsce pobytu stwarzało okazję do różnych domysłów w tej sprawie, a cała sytuacja budziła poważne obawy, łącznie z plotką o śmierci więźniów. Sołtyk - analogicznie jak król Władysław - był oczekiwany w kraju. W obu utworach występuje motyw zdrady i wygnania, a zarysowany na koniec kontekst „prorocki” (dzięki pomocy Bożej) napawa optymizmem. Co więcej, losy obu, króla i biskupa, wykorzystywano dla celów politycznych i religijnych.

Utwór Lamentacyja Jeremijasza nad Krakowem dobrze dopełnia relacja o charakterze kronikarskim pod tytułem Opisanie oblężenia miasta Krakowa od wojska rosyjskiego, kończąca się akapitem:
\Dnia I7 tegoż [I7 sierpnia I768 roku - K. M.] nieprzyjaciel o godzinie I2 $\mathrm{w}$ nocy począł ze wszystkich stron atakować miasto [...] za bramy powoli postępował pod ratusz, z ręcznej broni nieustannie w okna, w domostwa po wszystkich ulicach dając ognia [...], a jego mość pan Apraksin [Piotr Fiodorowicz - K. M.] generał wojsk rosyjskich, poje- chawszy do konfederatów $[\ldots]$ broń od jego mości marszałka [Michała Czarnockiego - K. M.] odebrał, i inni złożyć musieli; a nazajutrz, to jest dnia I8 tegoż, wszędzie rewizyje były po wszystkich klasztorach,

16 Wierszowany list króla Wtadystawa, w: Średniowieczna poezja tacińska w Polsce, oprac. M. Włodarski, Wrocław 2007, s. LXIII-LXV i 109-114. 
a $\mathrm{z}$ tych pozbierawszy konfederatów, we dwa tygodnie do Kijowa odesłali $[\ldots]^{17}$.

Epilog upadku Krakowa mógł przywodzić na myśl uprowadzenie Sołtyka, które odbyło się w nocy, a jego bezbronność wobec wysłanych po niego sił rosyjskich - przypominać poddanie się konfederatów generałowi Apraksinowi. Ponadto wprowadzony do relacji wątek represji we wszystkich klasztorach Krakowa mógł nabierać szczególnego znaczenia w kontekście przebywania w niewoli biskupa krakowskiego.

Zestawianie Sołtyka z niezwykłymi postaciami miało przekonywać o jego wyjątkowości, do czego - oprócz zniewolenia - predysponowały go posiadane przezeń cnoty. Widziano w nim ideał godny naśladowania. Taki wizerunek biskupa kreowali poeci, zwłaszcza wywodzący się z jego kręgu rodzinnego.

Jako wzór postępowania przedstawiał swego stryja Maciej Kajetan Sołtyk, o którym obecnie sporo wiemy, głównie dzięki dociekliwości badawczej Barbary Wolskiej $^{\mathrm{I} 8}$ i Marii Czeppe ${ }^{\mathrm{I} 9}$. Ta druga ogłosiła anonimowy utwór Kanonik putkownikiem, czyli wierszowaną biografię Macieja Kajetana, która w wielu momentach nie jest budująca. Badaczka przywołała też wyrażoną przez Jacka Puttkamera opinię na temat Macieja Kajetana Sołtyka, która daje wiele do myślenia: „Sołtyk, kanonik, imię i charakter mający wysokiego szacunku, lecz modestii żadnej i hydliwej, rządzący się lekkomyślnością, na wuja swego biskupa paszkwile z Dzierżanowskim pisał i rabunkami się skalał na wielu miejscach”20. Zarówno ujęta w rymy biografia bratanka biskupa, jak i informacja przekazana przez Puttkamera mogą skłaniać do zastanowienia się nie tylko nad autorstwem przyznanych Maciejowi Kajetanowi ód pochwalnych pod adresem biskupa krakowskiego, ale również nad prawdziwością wynurzenia Puttkamera. Przywołajmy zatem fragment utworu Kanonik putkownikiem:

\section{\Stracił ksiądz pułkownik grosze \\ Przez nierząd i przez złe karty,}

17 Opisanie oblężenia miasta Krakowa od wojska rosyjskiego, oprac. J. Wójcicki, w: Literatura konfederacji barskiej, t. 4, s. 64-68.

18 Zob. B. Wolska, Wokót Sottyka. Trzy utwory polityczne z czasów konfederacji barskiej, „Archiwum Literackie”, t. 22: Miscellanea z doby Oświecenia, t. 5, Wrocław 1978, s. 19-52.

19 Zob. M. Czeppe, Kanonik putkownikiem, czyli ksiadz rotmistrz. Ksiadz Maciej Kajetan Sottyk, „Napis” 2002, seria VIII: Polemika i żart literacki, s. 79-89; wydanie utworu z rkpsu Biblioteki Jagiellońskiej (dalej: BJ), sygn. 5501, s. 83.

20 Polityka i ustrój Generalności Konfederacji Barskiej, dwa nieznane przyczynki, wyd. W. Konopczyński, „Archiwum Komisji Historycznej”, seria 2, t. 2 (ogólnego zbioru t. 14), Kraków 1930, s. 73. Zob. M. Czeppe, J. Śmiałowski, Sottyk Maciej Kajetan, hasło w: PSB, t. 40, s. 405. 


\section{A sądząc, że ujdą żarty \\ Rozgłosił, iż go łotr srogi \\ Okradł, nabawiwszy trwogi. \\ Przez szacowne stryja imię \\ Żałują go w całym Rzymie. \\ (w. IO-I6) $)^{21}$}

Cytowany passus odnosi się do pobytu Macieja Kajetana w Stolicy Apostolskiej, do której został wysłany z polecenia stryja. W świetle całego utworu bratanek biskupa, ksiądz pułkownik jawi się jako awanturnik i rymopis skłonny do konfabulacji. Ponadto autor wskazywał na jego „złą duszę”, nazywając go łotrem, karciarzem i człowiekiem nierządnym, a odnosząc się do jego zapędów poetyckich - półgłówkiem („poeta z pół głowy”, w. 77), kierującym się w pisaniu chęcią zemsty. Jednocześnie nie odmawiał mu talentu rymopisa („niezłe bajki kleci”, w. 7I) i zręczności w manipulowaniu prawdą:

\section{\Umie zmyślać, umie zwodzić \\ I fałsz jawny z prawdą zgodzić.$$
(\text { w. } 69-70)^{22}
$$

Biskup krakowski potępił z całą surowością postępowanie swego synowca i niezwykle emocjonalnie zareagował na doniesienia o nim, do tego stopnia, że „aż włosy na głowie mu powstały"23. Próbując wpłynąć pozytywnie na sprawiającego kłopoty Macieja Kajetana, wcześniej polecał go pieczy kanonika Józefa Olechowskiego. W jednym z listów do czuwającego nad bratankiem „opiekuna” zawarł apodyktyczne żądanie: gdyby „postępki” bratanka „były zdrożne - imieniem moim pisz do niego odwracając go od nich" ${ }^{24}$. Sam też biskup - podają autorzy biogramu Macieja Kajetana Sołtyka - „karcił listownie” bratanka ${ }^{25}$, ganiąc jego ekscesy. Nie można zatem wykluczyć, że urażony reprymendą od stryja Maciej Kajetan mógł odwzajemniać się mu pisanymi nań tekstami szkalującymi.

Pozostaje jeszcze sprawa paszkwilów na biskupa, mających wychodzić spod ręki Michała Dzierżanowskiego. Niewątpliwie był on podejrzaną figurą i miał złą opinię.

21 M. Czeppe, Kanonik putkownikiem..., s. 88-89.

22 Ibidem.

23 Za: ibidem, s. 83 - list z Warszawy 27 marca 1773 r., rkps Biblioteki PAN/PAU w Krakowie, sygn. 320 .

24 Za: B. Wolska, Wokót Sottyka..., s. 28 - list K. Sołtyka do J. Olechowskiego, Kaługa 16 września 1772 r., rkps BJ 5434, s. 64.

25 Zob. M. Czeppe, J. Śmiałowski, Sottyk Maciej Kajetan, s. 405. 
Mikołaj Repnin pisał o nim: „we wszystkich czterech częściach świata robił szelmostwa” i - jak sądził - „wszędzie zasłużył na stryczek”, a z drugiej strony „coś gadał bezbożnie na wiarę", co w domniemaniu Władysława Konopczyńskiego mogło być gardłowaniem „za tolerancją dla różnowierców” ${ }^{26}$. Czy Michał Dzierżanowski rzeczywiście mógł pisać paszkwile na więzionego Sołtyka, trudno powiedzieć. Brakuje danych, aby to jednoznacznie stwierdzić, chociaż połączenie przez Puttkamera Macieja Kajetana Sołtyka z Dzierżanowskim ma wspólny mianownik: w czasach konfederacji barskiej obaj domniemani paszkwilanci byli znani z awanturniczego stylu życia.

Odnosząc się do Macieja Kajetana Sołtyka, wypada zapytać, czy wybryki bratanka, a także związane $\mathrm{z}$ tym reprymendy od stryja, nie stoją $\mathrm{w}$ sprzeczności z jego wierszami pochwalnymi pod adresem przebywającego w niewoli biskupa. Silnym argumentem przemawiającym za twórczością pochwalną na rzecz stryja były z pewnością więzy rodzinne, jak też jego aktualne położenie, czyli pobyt w niewoli. To dostateczna podstawa do tego, by troszczyć się o życie więźnia, a może nawet rehabilitować się za stworzone pod wpływem chwili paszkwile, zwłaszcza że pisane przez bratanka wiersze pochwalne na cześć tego członka rodu tchną autentycznością.

Oddajmy więc głos Maciejowi Kajetanowi i przyjrzyjmy się jego wybranym utworom o takim charakterze.

Oda do Księcia Jego Mości Sottyka, biskupa krakowskiego od Jego Mości Księdza Kajetana Sottyka kanonika krakowskiego, synowca, pisana [...] I767 rozpoczyna się apostrofą skierowaną do stryja:

\section{Zbyt drogi stryju, którekolwiek kraje, Mając cię, widzą przykład cnoty żywy, Dzikie w łagodne mienić obyczaje Muszą, miłymi ściągnieni ogniwy. $(\text { w. I }-4)^{27}$}

W słowach tych bratanek podzielał powszechne, wychodzące poza granice kraju, przeświadczenie o przykładnej cnocie biskupa jako wzoru postępowania. Poeta miał świadomość, jak ważną osobą dla rodaków, w tym także dla niego, jest jego stryj. Wskazując na najlepsze cechy adresata ody, takie jak „,czyste sumienie”, „umysł bez

26 W. Konopczyński, Dzierżanowski Michat, hasło w: PSB, t. 6, Kraków 1948, s. 157.

27 Oda do Księcia Jego Mości Soltyka, biskupa krakowskiego od Jego Mości Księdza Kajetana Sottyka kanonika krakowskiego, synowca, pisana z okoliczności wzięcia w areszt moskiewski tegoż Księcia Jego Mości Biskupa 1767, oprac. B. Wolska, w: Literatura konfederacji barskiej, t. 3, s. 58-62. 
skazy”, odwaga, pobożność i patriotyzm oraz chęć poświęcenia życia w imię obrony najwyższych wartości, ujawniał swój podziw i szacunek dla więzionego biskupa:

\section{Dajesz, cny stryju, w tobie widok żywy, Gruntownej wiary, miłości ojczyzny... Czyste sumienie i umysł bez skazy Nie umie służyć, choć ciało w niewoli. Raczej okrutne śmierci odnieść razy, Niż zakał przynieść swojej cnocie woli... $\mathrm{Na}$ stały umysł świat się niech obali, Ciężar ten będzie cnocie jeszcze mały. (w. I45-I5O) $)^{28}$}

Było to nie tylko osobiste spojrzenie bratanka na przedstawiciela rodu, ale postrzeganie go przez pryzmat widzenia ogółu, w szczególności podległego Sołtykowi duchowieństwa, a więc osób dobrze go znających. W pewnym sensie jest to utwór pisany w imieniu przedstawicieli tego stanu. Stworzony z takiej perspektywy wizerunek biskupa miał za zadanie uwiarygodnić ten obraz.

Z autorstwem Macieja Kajetana Sołtyka jest także łączona oda Dzieto smutku Kajetana Sottyka [...] Roku Pańskiego I768, nasycona - jak wskazuje tytuł - nuta elegijną, adekwatną do rangi wydarzenia, czyli aresztowania „gwałtem wydartego” biskupa $^{29}$. Powtarzane po wielokroć w wierszu słowa: $\dot{z} a l$ (,serce ściska żal”, w. 5-6), żatość („żałość skryta”, w. 30), udręka („dręczy serce”, w. 30, 38), tzy („we łzach tonące... oczy”, w. 9; „łza łzę... tłoczy”, w. Io), smutek („smutna dusza”, w. 7), gorycz („dusza pełna... goryczy”, w. 49), smętność, samotność i tym podobne - miały oddać przeżycia bratanka, pragnącego dzielić los z uwięzionym. Autor nie ma wątpliwości, że stryj stał na straży wiary katolickiej i gdyby nie przebywał w niewoli, ten fundament istnienia Rzeczypospolitej nie doznałby uszczerbku. Teraz, gdy „wolność ginie/ I wiary całość w ciężkim jest terminie” (w. 51-5I), uwięziony Sołtyk - jak obwieszcza poeta - daje najlepszy przykład poświęcenia dla kraju.

Kolejny utwór (Z okoliczności wzięcia w areszt przez Moskwę księcia Sottyka biskupa krakowskiego) skierował Maciej Kajetan Sołtyk do swego kuzyna księdza Michała Sołtyka, kantora krakowskiego ${ }^{30}$. Adresata ody łączyły z biskupem nie tylko więzy

28 Ibidem.

29 Dzieto smutku Kajetana Sottyka kanonika krakowskiego i warszawskiego i scholara tęczyckiego, w tym rękopisie zebrane w Kielcach Roku Pańskiego 1768, oprac. J. Maciejewski, B. Szleszyński, w: Literatura konfederacji barskiej, t. 3, s. 51-53.

30 Zob. Oda do Jego Mości księdza Michata Sottyka kantora krakowskiego, w Rzymie bawiacego, od Jego Mośi księdza Kajetana Sottyka kanonika krakowskiego pisana z okoliczności wzięcia w areszt przez Moskwe księcia Sottyka biskupa krakowskiego, oprac. B. Wolska, w: Literatura konfederacji barskiej, t. 3, s. 54-57. 
rodzinne, ale też zawodowe zobowiązania. W Rzymie, do którego przybył z polecenia stryja, był jego przedstawicielem przy Watykanie. Gdy doszła do niego wiadomość o gwałcie zadanym senatorom przez Repnina, usiłował zaangażować w sprawę obu kolejno panujących papieży: Klemensa XIII i Klemensa XIV ${ }^{\text {II }}$.

Maciej Kajetan Sołtyk jest przekonany, że okrucieństwo, jakiego doświadcza wielki członek ich rodu, to cios, który uderza zarówno w niego, jak i w kuzyna Michała. W poczuciu solidarności rodzinnej pisał:

\section{\Wieść, która równo ciebie i mnie dotyka, \\ Mniemam, że spieszno tamte kraje mija: \\ Wiara i wolność straciła Sołtyka, \\ A nam obydwom odebrali stryja. \\ Okrutne czasy! Łzy z oczu wyciska \\ Samo wspomnienie takiego nazwiska! \\ (w. $25-30)^{32}$}

Krzywda, jakiej doznaje biskup, budzi w autorze lęk o życie więźnia, a ponadto wyzwala gorzką refleksję związaną z koniunkturalnymi zachowaniami ludzi:
》 Niemiłe przy tym w tym kraju jest życie,
Gdy wiarę, wolność tracimy i stryja.
Źli tylko sami teraz są w zaszczycie,
Do portu szczęścia z nich każdy zawija.
Dobra i życie cnotliwych na szali,
Cud, gdy nie zginą w tak burzliwej fali.
(w. 9I-96) ${ }^{33}$

A co najgorsze, nawet dotychczasowi sprzymierzeńcy biskupa Sołtyka sprawili zawód. Poeta dokonał oceny ich postępowania w słowach:

\section{\ Którzy naszego stryja przyjaciele \\ Byli, niewarci tego są nazwiska. \\ Przeciwnej stronie teraz służą śmiele, \\ Gdy go surowość więzienia przyciska.}

31 Zob. J. Śmiałowski, Sottyk Michat, hasło w: PSB, t. 40, s. 415. Tam też między innymi informacja, że Maciej Sołtyk zamówił u Franciszka Smuglewicza obraz upamiętniający powrót biskupa z niewoli do kraju.

32 Oda do Jego Mości księdza Michata Sottyka kantora krakowskiego..., s. 55.

33 Ibidem, s. 57. 
Niegodzien żaden imienia Polaka,

Gdy się zapiera w nieszczęściu rodaka.

(w. 6I-66) $)^{34}$

Nazwiska tych rzekomych przyjaciół Sołtyka wskazywano wprost w wielu krążących wówczas wierszach. Często krytykowano prymasa Gabriela Podoskiego. W Addytamencie do cyklu Zdanie o biskupach jest on wyjątkowo marną kreaturą, wiarołomnym zdrajcą, napiętnowanym za niewdzięczność wobec Sołtyka, który konsekrował go na biskupa, czego nie omieszkał wypomnieć mu autor wiersza:

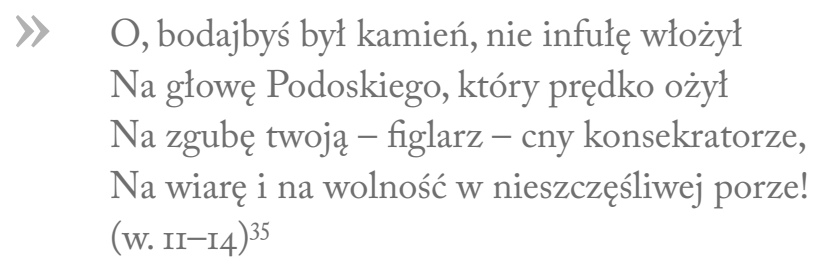

Krętacz Podoski („Że wiarołomca, lutrów adherent widomy/ Schizmatyków, kalwinów obrońca kryjomy”, w. 7-8) grzeszy nadto rozwiązłością; jego związek z protestantką zwaną Emkinią, małżonką dobrze prosperującego kupca (połączonego interesami handlowymi $\mathrm{z}$ ministrem Heinrichem Brühlem), zasługiwał na szczególne potępienie ${ }^{36}$.

Poeci nie mieli wątpliwości, że zdrajcy i wiarołomcy, a także zwyczajni tchórze (jako że zbyli milczeniem porwanie Sołtyka) przykładają rękę do zguby ojczyzny.

Gdy tak zestawiano Kajetana Sołtyka z ludźmi nikczemnymi, jego postać świeciła cnotą, a pobyt w niewoli przydawał mu aureolę świętości. On bowiem, nie zważając na konsekwencje, przeciwstawił się „dzikości szkaradnych nienawistnych ludzi”, „czartom przeklętym”, „monstrom plugawym”, ,niegodnym wyrodkom”, którzy "przez pychę i złość wściekłą” gubią wiarę i bluźnią Bogu, „radząc podchlebnie moskiewskiej kobiecie" ${ }^{37}$.

34 Ibidem, s. 56.

35 Sottyk biskup krakowski (w cyklu Addytament wyroków nad biskupami w Koronie Polskiej i Wielkim Księstwie Literwskim ozięble broniącymi wiary świętej katolickiej rzymskiej podczas sejmu ekstraordynaryjnego w Warszawie die 5 Octobris anno 1767), oprac. J. Maciejewski, w: Literatura konfederacji barskiej, t. 3, s. 31.

36 Emkini, metresa prymasa, czyli pani Oemingen (Oemichen, Oemchen), jest „bohaterką” wiersza Opisanie nabożnej księcia prymasa przytomności na procesyi podczas Bożego Ciała 1768 w Warszawie, oprac. K. Wąsala, w: Literatura konfederacji barskiej, t. 3, s. 250-252. Zob. też R. Kaleta, Oświecenie swawolne w świetle nieznanej satyry bibliograficznej, w: idem, Oświeceni i sentymentalni. Studia nad literatura $i$ życiem w Polsce w okresie trzech rozbiorów, Wrocław 1971, s. 249. W epigramacie Prymas Podoski (w cyklu Addytament wyroków nad biskupami..., t. 3, s. 32) Podoski to „krzywoprzysiężnik i amant publiczny/ Emchinowej luterki” (w. 5-6).

37 M.in. [Czarci przeklęci, zrobiliście piekto...], oprac. A. Bąbel, J. Maciejewski, w: Literatura konfederacji barskiej, t. 3, s. 87. 
Niewola Sołtyka wpłynęła na jego niebywałą popularność. Portrety biskupa znajdowały się w wielu domach; niewiasty szczyciły się talizmanami z jego podobizną. Szczególną satysfakcję z posiadania miniaturki Sołtyka ujawniała Katarzyna Kossakowska ${ }^{38}$, dama nieprzejednana w swej niechęci do Stanisława Augusta. Uwielbienie, jakim darzono biskupa, wzmagało nienawistny stosunek do niego ze strony Rosjan. Dzięki relacji z Biecza z 5 kwietnia I77o roku dowiadujemy się, że gdy oficer rosyjski zauważył na plebani bieckiej wiszący na ścianie portret Sołtyka, uznał mężczyznę za winnego nieszczęścia Polski, w tym złupienia Biecza ${ }^{39}$. Było to wyjątkowo perfidne oskarżenie.

Poeci obawiali się o los więzionego biskupa - męczennika, gotowego bronić rzymskiej wiary katolickiej kosztem własnego życia. Ta determinacja pasterza sprawiała, że nadzieję na jego powrót widziano przede wszystkim w Opatrzności Boskiej. Taki pogląd ujawniał między innymi autor Dumy nad wzięciem w niewole Jaśnie Oświeconego Księcia Jego Mości Biskupa Krakowskiego, Księcia Siewierskiego za obstawanie przy wierze $i$ wolności... (datowany na 25 października 1767 roku). Poeta ten, zwracając się do biskupa, nie tracił nadziei w sytuacji:

\section{Gdy cię umysłu wspaniałość nakłania \\ Byś dla wiary ginął ochoczy, \\ Bóg też wysłucha nasze płacze, łkania \\ Twym powrotem otrze nam oczy... \\ (w. $\left.57^{-60}\right)^{40}$}

Obecny w dumie starotestamentowy motyw opieki Boga nad człowiekiem, Boga niosącego pomoc i budzącego ufność, pozwalał niezłomnie wierzyć w ocalenie więźnia.

Aby nadać oczekiwaniu na biskupa powszechny charakter, prośby błagalne do Boga o jego powrót z niewoli - jak czytamy w odzie autorstwa synowca biskupa, jego imiennika Kajetana - wypowiadano w imieniu pospólstwa:

38 Zob. K. Maksimowicz, Z jakiego powodu komplementowano Katarzyne Kossakowska?, w: Panegiryk jako element życia literackiego doby staropolskiej i oświeceniowej, red. M. Sulejewicz-Nowicka, Z. Gruszka, ze wstępem M. Wichowej, Łódź 2013, s. 211 (na podst. rkpsu BJ 6799, k. 21: „Z Warszawy, d. 18 VII 1771").

39 Zob. Relacje o gwałtach rosyjskich w Bieczu (wersja 1: Postępek niegodziwy wojska rosyjskiego w Bieczu wykonany die 5 Aprilis 1770 anno; wersja 2: Postępek szkaradny przez wojsko moskiewskie w mieście grodowym Bieczu die 5 kwietnia 1770 wykonany, a przez tego, który na to patrzyt, opisany), oprac. J. Maciejewski, M. Rudkowska, w: Literatura konfederacji barskiej, t. 4, s. 77-82.

40 Duma nad wzięciem w niewole Jaśnie Oświeconego Księcia Jego Mości Biskupa Krakowskiego, Księcia Siewierskiego za obstawanie przy wierze i wolności die 25 Novembris 1767 napisana, oprac. A. Bąbel, w: Literatura konfederacji barskiej, t. 3, s. 48-50. 
》Wznosi omdlałe lud ręce w niebiosy,

Żebrząc w niedoli od Boga pomocy.

Jęczenia słychać i płaczliwe głosy,

W dzień nader przykre, okropniejsze w nocy.

Widząc nieszczęścia znaki zbyt dokładne,

W smutku się topi pospólstwo bezradne.

(w. $\left.43^{-48}\right)^{41}$

W Bogu pokłada też nadzieję sam uwięziony. Autor Ody, w której Wolność z ptaczem rozmawia i utyskuje na czas teraźniejszy... włożył w jego usta słowa skierowane do Wolności:

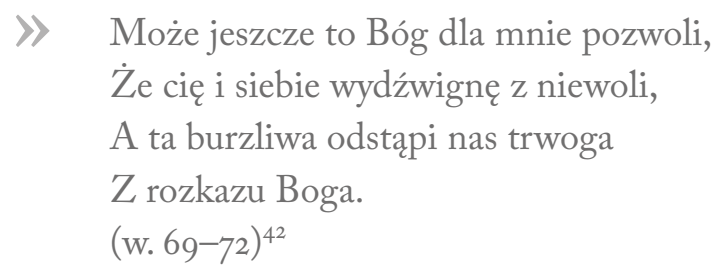

Wiążąc ingerencję Wszechmocnego z uwolnieniem Sołtyka czy wręcz ze sprawą narodową, poeta stawiał znak równości między oswobodzeniem biskupa a wolnością kraju, i grając na nucie patetycznej, dokonywał sakralizacji więźnia za życia. Takie jest marzenie Wolności:

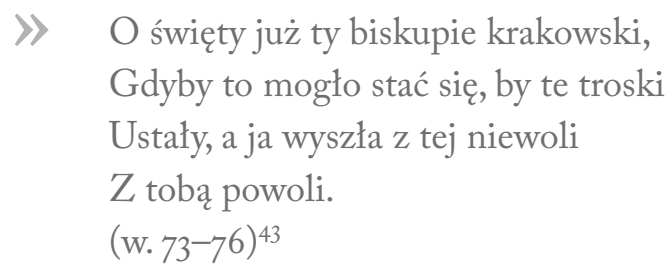

Chyba jeszcze dalej w swym uniesieniu patriotycznym poszedł Maciej Kajetan Sołtyk w Odzie do Jaśnie Oświeconego Księcia Jego Mości Soltyka biskupa krakowskiego $z$ niewoli dla wiary $i$ wolności podjętej do ziomków w trzech stanach na reasumpcje sejmu zgromadzonych..., z datacją: 20 Januarii 1768 . Ten popularny współcześnie

41 Oda do Księcia Jego Mości Sottyka, biskupa krakowskiego od Jego Mości Księdza Kajetana Sottyka kanonika krakowskiego, synowca..., t. 3, s. 59.

42 Oda, w której Wolnośc z ptaczem rozmawia i utyskuje na czas teraźniejszy, stanq̨wszy w senacie, oprac. J. Maciejewski, w: Literatura konfederacji barskiej, t. 2, s. 33-37.

43 Ibidem. 
utwór był wierszowanym listem rzekomego autorstwa biskupa krakowskiego; to $\mathrm{z}$ jego ust padają słowa pełne dumy:

\Wielką to dla mnie będzie zawsze chlubą, Gdy wiarę, wolność ocalę mą zgubą (w. 5-6),

a czas pobytu w niewoli przyjmuje jako dobrodziejstwo:

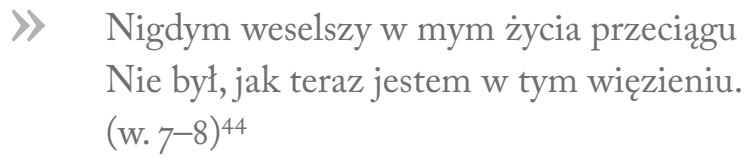

Mimo uwięzienia nie traci hartu ducha:

$$
\begin{aligned}
& \text { Jestem więziony, lecz tylko na ciele, } \\
& \text { Przetom też ciałem jest od was daleki, } \\
& \text { Lecz umysł wolny z wami zawsze śmiele } \\
& \text { Komu występek nie krępuje serca, } \\
& \text { Żaden go więzić nie zdoła morderca. } \\
& \left(\text { w. } 3^{\mathrm{I}-36)^{45}}\right.
\end{aligned}
$$

Pobyt w niewoli za wolność i wiarę jest sprawdzianem wielkości biskupa. Składając ofiarę ze swego życia, był przekonany, że niewola ta nie będzie próżna. Barbara Wolska dostrzega wyraźne podobieństwo fragmentu tego utworu $\mathrm{z}$ autentycznym tekstem Sołtyka, tak zwanym testamentem pasterskim (Pożegnanie Ksią̇ęcia Jego Mośi Sottyka biskupa krakowskiego dla diecezyi swojej zostawionego...), sporządzonym na wypadek aresztowania. Zdaniem tej badaczki autor ody „do ziomków [...] na reasumpcję sejmu zgromadzonych” oddal „ton i ducha” testamentu Sołtyka ${ }^{46}$. Pewien trop w kierunku poszukiwań twórcy wiersza „do ziomków” wskazał Stanisław Ludwik Krowicki, który wziął pod uwagę odezwę pod tytułem List do Prześwietnego Senatu

44 Oda do Jaśnie Oświeconego Księcia Jego Mości Sottyka biskupa krakowskiego z niewoli dla wiary i wolności podjętej do ziomków w trzech stanach na reasumpcje sejmu zgromadzonych die 20 Ianuarii 1768 pisana, oprac. B. Wolska, w: Literatura konfederacji barskiej, t. 3, s. 63-70. Ten sam utwór, ale z datą 16 Jan[uarii] 1768 (w innym rękopisie) wskazał Stanisław Ludwik Krowicki w artykule Rzekomy list biskupa krakowskiego Kajetana Ignacego Sottyka „z niewoli moskiewskiej” do Senatu i polskiego rzadu („Krakowski Rocznik Archiwalny”, t. 23, Kraków 2017, s. 171). Tenże autor cytuje też jedną strofę z wiersza, w. 163-168.

45 Oda do Jaśnie Oświeconego Księcia Jego Mości Sottyka biskupa krakowskiego..., s. 63.

46 Ibidem, s. 64. 


\section{i Ministerium Polskiego od Jaśnie Oświeconego Księcia Jegomości Biskupa Krakowskiego} w niewoli Moskierwskiej zostajacego bez daty pisany. Badacz ten domniemywal, że autor odezwy należał do kręgu biskupa kamienieckiego, Adama Stanisława Krasińskiego. W swych rozważaniach poszedł jeszcze dalej, akcentując podobieństwo stylistyczne (figury retoryczne) Listu... z „odezwą Krasińskiego do narodu przed sejmikami z i6 listopada 1790 roku" ${ }^{4}$. Jak by w rzeczywistości nie było, zakamuflowane autorstwo twórcy ody adresowanej „do ziomków [...] na reasumpcję sejmu zgromadzonych”, stwarzające pozory faktycznego zwrotu więźnia Repnina do rodaków, wynikało z przekonania o sile autorytetu porwanego biskupa. Ten autorytet miał być szczególnie pomocny w najważniejszych momentach, a takim niewątpliwie był zamiar wprowadzenia do sejmu „złych odszczepieńców”. Głos Sołtyka wzywał do oporu.

Podróbki literackie polegające na przyznawaniu biskupowi krakowskiemu autorstwa odezwy z niewoli do decydujących o losach kraju powstawały jako reakcje na realną groźbę utraty wolności i politycznej suwerenności Polski. Ten chwyt mistyfikacyjny zastosuja poeci jeszcze nieraz, wprowadzając postać Sołtyka w kluczowych dla ojczyzny sprawach, także po jego śmierci.

Pięcioletni czas pobytu w niewoli Kajetana Sołtyka zaowocował szerokim nurtem poezji pochwalno-agitacyjnej, budzącej żal i wskazującej na zniewagę narodu polskiego, a nade wszystko oddającej miłość i ogromny szacunek do biskupa za obronę najwyższych wartości. I chociaż utwory te nie należą do szczególnie oryginalnych, cechuje je bowiem wznawialność podejmowanych wątków, to sposób kreacji konterfektu bohatera prowadził go do legendy poetyckiej, a powtarzając za autorem Rozmowy na Polach Elizejskich między Janem Zamoyskim kanclerzem niegdys $i$ hetmanem wielkim koronnym, $i$ Eustachym Potockim, generatem artylerii litewskiej, dnia 24 lutego I768 roku w Warszawie zmartym, nie da się nie zauważyć, że Kajetan Sołtyk należy do tych „mężów, których imiona sława w księgach wieczności niezmazanymi wyryła literami” („wzór do naśladowania w najpóźniejsze wieki”, „nieustraszone serce, a nad to wszystko najszacowniejsza... cnota”) ${ }^{48}$.

\section{BIBLIOGRAFIA}

Czeppe M., Kanonik putkownikiem, czyli ksiądz rotmistrz. Ksiadz Maciej Kajetan Sottyk, „Napis” 2002, seria VIII: Polemika i żart literacki.

Sottyk Kajetan Ignacy, hasło w: Polski stownik biograficzny, t. 40, Warszawa 2001.

Czeppe M., Śmiałowski J., Sołtyk Maciej Kajetan, hasło w: Polski stownik biograficzny, t. 40, Warszawa 2001.

47 S.L. Krowicki, Rzekomy list biskupa krakowskiego..., s. 167.

48 Temat dialogów zmarłych, w kontekście biskupa Sołtyka, omawia Zofia Sinko, Oświeceni wśród Pól Elizejskich. Rozmowy zmartych: recepcja - twórczość oryginalna, Wrocław 1976, s. 178-185 (seria „Studia z okresu Oświecenia”, t. 14). Cyt. za: ibidem. 
Harris J., Dziennik pobytu w Polsce 1767, tłum. Z. Lewinówna, w: Polska stanistawowska w oczach cudzoziemcórw, t. 1, oprac. i wstępem poprzedził W. Zawadzki, Warszawa 1963.

Konopczyński W., Dzierżanowski Michat, hasło w: Polski stownik biograficzny, t. 6, Kraków 1948.

Krowicki S.L., Rzekomy list biskupa krakowskiego Kajetana Ignacego Sottyka „z niewoli moskierwskiej” do Senatu i polskiego rządu, „Krakowski Rocznik Archiwalny”, t. 23, Kraków 2017.

Literatura konfederacji barskiej, t. 1: Dramaty, t. 2: Dialogi, t. 3: Wiersze, t. 4: Silva rerum, red. J. Maciejewski, A. Bąbel, A. Grabowska-Kuniczuk, J. Wójcicki, Warszawa 2005-2009.

Maksimowicz K., Z jakiego powodu komplementowano Katarzynę Kossakowska?., w: Panegiryk jako element życia literackiego doby staropolskiej i oświeceniowej, red. M. Sulejewicz-Nowicka, Z. Gruszka, ze wstępem M. Wichowej, Łódź 2013.

Mowa J.O. Księcia Jmci Sottyka biskupa krakowskiego die 13 8-bris 1767 do Senatu przygotowana, ale dla wzięcia tegoż Księcia w areszt przez Moskwe w Senacie nie miana, tylko na sesji prowincjonalnej matopolskiej czytana, rkps BUW 274, t. 1 (w: Rękopis czyli zbiór rozmaitych pisem jako to politycznych krajowych, historycznych $i$ ciekawych etc...).

Pamiętniki króla Stanistawa Augusta. Antologia, wybór tekstu D. Triaire, tłum. W. Brzozowski, wstęp A. Grześkowiak-Krwawicz, red. M. Dębowski, Warszawa 2013.

Polityka i ustrój Generalności Konfederacji Barskiej, dwa nieznane przyczynki, wydał W. Konopczyński, „Archiwum Komisji Historycznej”, seria 2, t. 2 (ogólnego zbioru t. 14), Kraków 1930.

Schulz F., Podróże Inflantczyka z Rygi do Warszawy i po Polsce w latach 1791-1793, tłum. J.I. Kraszewski, w: Polska stanistawowska w oczach cudzoziemców, t. 2, oprac. i wstępem poprzedził W. Zawadzki, Warszawa 1963.

Sinko Z., Oświeceni wśród Pól Elizejskich. Rozmowy zmartych: recepcja - twórczość oryginalna, Wrocław 1976.

Ślęczka T., Historia Polski w literaturze barskiej. Próba charakterystyki, w: Poezja okolicznościowa w Polsce w latach 1730-1830. W kregu spraw publicznych i narodowych, red. M. Nalepa, G. Trościński, R. Magryś, Rzeszów 2014.

Śmiałowski J., Sottyk Michat, hasło w: Polski stownik biograficzny, t. 40, Warszawa 2001.

Wierszowany list króla Wtadystawa, w: Średniowieczna poezja tacińska w Polsce, oprac. M. Włodarski, Wrocław 2007.

Wolska B., Wokót Soltyka. Trzy utwory polityczne z czasów konfederacji barskiej, „Archiwum Literackie”, t. 22: Miscellanea z doby Oświecenia, t. 5, Wrocław 1978.

SŁOWA KLuCze: Kajetan Sołtyk, niewola kałuska, wiersze okolicznościowe, konfederacja barska

\section{Krystyna Maksimowicz}

\section{AT THE SOURCE OF THE POETIC LEGEND OF KRAKÓW'S BISHOP, KaJETAN SOŁTYK}

Literature of the Bar Confederation created a positive legend of the Kraków's bishop, Kajetan Sołtyk. Its point of birth was the abduction of the bishop from 
Warsaw Sejm (Parliament) of I767. At that Sejm, the bishop became famous for being one of the main leaders opposing equality for dissidents, for which he paid with over five years in Russian captivity. The authors of the Bar poems used in this article concentrated on the martyrdom of the prisoner, his unshaken attitude and the readiness to sacrifice his life for the Catholic faith. They would place him in the context of saints, biblical characters and heroes of antiquity, who were paragons of behaviour.

The poems highlighted in the study are largely laudatory or canvassing in character - they call for not yielding on the issue of dissidents.

KeY words: Kajetan Sołtyk, Kaluga imprisonment, occasional poems, Bar Confederation 